\title{
PENGEMBANGAN DESAIN PEMBELAJARAN MATEMATIKA SEKOLAH DASAR KELAS 1
}

\author{
DWI SETIA NINGRUM \\ wiilova.styand@gmail.com \\ 085716668530
}

LEONARD

leonard@unindra.ac.id 081382939050

\author{
Program Studi Pendidikan Matematika, Fakultas Teknik, Matematika \& IPA \\ Universitas Indraprasta PGRI
}

\begin{abstract}
Abstrak. Penelitian pengembangan ini bertujuan untuk membuat sebuah desain pembelajaran yang efektif bagi peserta didik Sekolah Dasar kelas 1 guna memfasilitasi pengembangan proses pembelajaran matematika berdasarkan penilaian ahli, ketercapaian kemampuan pemecahan masalah, serta respon peserta didik. Prosedur pengembangan diadaptasi dari model pengembangan instruksional M. Atwi Suparman yang meliputi tahap definisi, analisis dan pengembangan prototype sistem, serta melaksanakan evaluasi formatif. Produk yang dihasilkan berupa buku model pembelajaran, lembar kegiatan siswa, dan tes hasil belajar peserta didik. Produk ini telah beberapa kali direvisi berdasarkan saran dan masukan dari dosen pembimbing, validator, dan uji coba terbatas. Hasil yang diperoleh menunjukkan bahwa (1) kualitas bahan pembelajaran Matematika SD kelas 1 berdasarkan penilaian ahli tergolong baik; (2) respon siswa terhadap produk bahan pembelajaran tergolong sangat positif. Setelah menggunakan desain pembelajaran Matematika diharapkan dapat memfasilitasi siswa maupun guru Sekolah Dasar dalam pembelajaran Matematika Kelas 1 SD.
\end{abstract}

Kata kunci : Desain pembelajaran, pembelajaran matematika, SD Kelas 1

\begin{abstract}
This research aimed to make the development of an effective instructional design for Elementary School student's class 1 to facilitate the development of mathematics learning process based on expert assessment, the achievement of problemsolving abilities, and the student's response. The development Procedure is adapted from instructional development models M. Atwi Suparman including the step definition, analysis and development of a prototype system, and conducting formative evaluation. The yielded products included of book learning model, student activity sheets, and student test results. This product has several times revised based on suggestions and feedback from lecturers, validators, and limited testing. The results showed that (1) the quality of the Mathematics learning materials Grade 1 of Elementary School based on expert assessment is fair; (2) the students response to the learning material products classified as very positive. After using Math instructional design is expected to facilitate either students or teacher of elementary school in Mathematics Learnig Grade 1.
\end{abstract}

Keywords: Learning design, mathematic learning, elementary school class 1

\section{PENDAHULUAN}

Perkembangan zaman yang semakin modern pada arus globalisasi saat ini menuntut adanya sumber daya manusia yang berkualitas tinggi. Peningkatan sumber daya manusia merupakan syarat mutlak untuk mencapai tujuan pembangunan. Seperti yang 
dikemukakan oleh Sinamo (2010: 241) "Pendidikan dipandang sebagai jalan menuju manusia yang cerdas lagi cendekia, beretos kerja dan beretika mulia, bahkan sebagai marga utama menuju kesempurnaan hidup". Hasil dari pendidikan nantinya sangat diperlukan dalam pembangunan suatu bangsa.

Makna pendidikan tidak hanya mencakup pengembangan intelektual saja, namun pembinaan kepribadian peserta didik perlu dibimbing hingga mereka bisa lebih mengarahkan sikap, emosi, dan perilakunya. Oleh sebab itu, sekolah sebagai penyalur utama pendidikan umumnya tidak hanya memfokuskan pembelajaran atau pengembangan kemampuan kognitif dan mengabaikan nilai-nilai kemanusiaan. Nilai-nilai kemanusiaan yang terabaikan akan berakibat pada maraknya terjadi penyimpangan didunia pendidikan. Natalius (2012) menemukan bahwa berdasarkan laporan Education for All Global Monitoring Report yang dirilis UNESCO 2011 bahwa Indonesia berperingkat 67 dari 127 negara dalam Education Development Index dan menghasilkan empat orang anak putus sekolah dalam setiap menitnya. Masih dikutip dari situs yang sama, kualitas guru di Indonesia juga mendapat sorotan tajam sebab lebih dari $50 \%$ guru tidak memiliki kualifikasi yang cukup untuk mengajar. Oleh sebab itu, penyelenggara pendidikan membutuhkan masukan antara lain menyangkut model-model pengembangan desain pembelajaran sebagai bagian yang tidak terpisahkan dari sistem pendidikan nasional.

Proses pendidikan tidak pernah terlepas dari kegiatan belajar dan pembelajaran didalam kelas. Pembelajaran merupakan aktifitas interaksi edukatif antara pembelajar dengan peserta didik dengan didasari oleh adanya tujuan baik berupa pengetahuan, sikap, maupun keterampilan. Pengertian lain tentang pembelajaran, menurut Gagne \& Brigss (Sujarwo, 2011: 3) adalah proses yang diselenggarakan oleh pendidik untuk membelajarkan peserta didik dalam belajar, bagaimana memperoleh dan memproses pengetahuan, keterampilan, dan sikap.

Implementasinya dapat terlihat dalam proses belajar. Belajar adalah kegiatan individu memperoleh perilaku dengan cara mempelajari dan mengolah pengetahuan. Seperti yang diungkapkan Hilgard dan Marquis (Sagala, 2011: 31) bahwa belajar merupakan proses mencari ilmu yang terjadi dalam diri seseorang melalui latihan, pembelajaran, dan sebagainya sehingga terjadi perubahan dalam diri.

Proses belajar dan pembelajaran dapat dilakukan di sekolah dalam berbagai jenjang dan jenis, salah satunya adalah pendidikan Sekolah Dasar. Pendidikan Sekolah Dasar (SD) sebagai jenjang paling dasar pada pendidikan formal yang memiliki peranan besar bagi keberlangsungan proses pendidikan selanjutnya. Dalam aplikasi pembelajarannya, matematika merupakan salah satu mata pelajaran yang dapat meningkatkan proses berpikir peserta didik. Menurut Suhendri (2011: 32) "Matematika adalah ilmu tentang bilangan, bangun, hubungan-hubungan konsep, dan logika dengan menggunakan bahasa lambang atau simbol dalam menyelesaikan masalah-masalah dalam kehidupan seharihari". Mata pelajaran ini mempunyai nilai-nilai pendidikan yang dapat membentuk kepribadian peserta didik dan dapat memberikan kesempatan kepada peserta didik untuk berpikir sehingga mereka dapat menyelesaikan masalahnya sehari-hari.

Menurut Soejadi (2000: 11) "Matematika adalah suatu ilmu yang memiliki objek tujuan abstrak, bertumpu pada kesepakatan dan pola pikir deduktif". Matematika memang memiliki faktor sulit bagi mereka yang ingin mempelajarinya, yakni karakteristik matematika yang abstrak sementara kemampuan abstrak peserta didik, khususnya kelas 1 yang masih rendah. Karakteristik kognitif pada usia ini yaitu sesuai dengan stage perkembangan yang ditemukan oleh Piaget (Frengky, 2011: 153) yaitu pada stage operasional kongkrit. Pada stage ini anak-anak memahami sesuatu lebih cepat dengan suatu yang kongrit, bukan abstrak. Hal inilah yang menjadikan tantangan bagi guru, 
khususnya guru matematika, untuk mampu menjadikan matematika yang abstrak itu menjadi "nyata" dalam benak peserta didik sekolah dasar kelas 1 .

Dalam meningkatkan mutu pendidikan, yaitu pada pembelajaran matematika, sekiranya perlu diupayakan pula peningkatan mutu dari proses pembelajaran itu sendiri. Mutu proses pembelajaran yang didalamnya terdapat suasana penunjang seperti perangkat pembelajaran yang dapat memenuhi kebutuhan belajar peserta didik sesuai dengan teori pembelajaran yang digunakan. Salah satunya adalah dengan membuat desain pembelajaran yang efektif. Menurut Yasin (2012: 2) "Pembelajaran efektif dapat dipahami sebagai suatu proses instruksional yang terstruktur". Sedangkan Dick and Reiser (Suherman,dkk. 2010: 3) merngartikan desain pembelajaran yaitu sebagai sebuah proses sistematis untuk merancang, mengembangkan, melaksanakan, dan mengevaluasi sebuah instruksi sehingga dapat digunakan untuk meningkatkan mutu pendidikan dalam memenuhi kebutuhan belajar peserta didik sesuai perkembangan kognitif secara aktif dan menyenangkan bagi peserta didik.

Melihat gambaran realitas pembelajaran yang terjadi selama ini, sama sekali tidak memberikan peluang kepada peserta didik untuk mengembangkan kreatifitas dan potensi yang ada pada dirinya. Selain itu, keaktifan guru kurang berperan dalam proses pendidikan. Hasil penelitian Asrori (2013: 19) menunjukkan bahwa desain pembelajaran merupakan disiplin ilmu yang berhubungan dengan pemahaman dan perbaikan satu aspek dalam pendidikan, yaitu proses pembelajaran. Tujuan dari kegiatan membuat desain pembelajaran adalah menciptakan sarana yang optimal untuk mencapai tujuan pembelajaran yang dikehendaki.

Dari hasil analisis lapangan diatas menunjukkan perangkat pembelajaran yang ada belum efektif dalam memaksimalkan potensi peserta didik sekolah dasar. Untuk itu, desain pembelajaran sekolah dasar kelas 1 perlu dikembangkan agar dapat memaksimalkan potensi-potensi yang dimiliki anak usia sekolah dasar.

\section{MODEL PENGEMBANGAN}

Jenis penelitian adalah Research and Developmental (R \& D) yang bertujuan untuk menghasilkan model pembelajaran matematika yang efektif dan menyenangkan bagi peserta didik Sekolah Dasar kelas 1. Produk yang dikembangkan adalah bahan instruksional, berupa buku modul pada pembelajaran matematika SD kelas 1 dengan prosedur pengembangan menggunakan Model Pengembangan Instruksional (MPI) M. Atwi Suparman yang terdiri dari tiga tahapan, yakni tahap definisi pengembangan, tahap analisis dan pengembangan prototype sistem, serta tahap evaluasi formatif.

Pada tahap definisi pengembangan, meliputi identifikasi kebutuhan instruksional dan menulis tujuan instruksional umum, analisis instruksional, serta identifikasi perilaku dan karakteristik awal peserta didik. Tahap analisis dan pengembangan prototype sistem, meliputi tujuan instruksional umum, alat penilaian hasil belajar, strategi instruksional, serta mengembangkan bahan instruksional. Tahap pelaksanaan evaluasi formatif, meliputi penelaahan oleh pakar dan revisi, evaluasi oleh 1-3 peserta didik dan revisi, serta uji coba dalam skala terbatas dan revisi.

\section{HASIL DAN PEMBAHASAN}

Desain model pembelajaran matematika SD kelas 1 yang diadopsi dari MPI diawali dengan analisis kebutuhan instruksional, identifikasi kebutuhan instruksional, menulis tujuan instruksional umum (TIU), analisis instruksional, identifikasi perilaku dan karakteristik awal peserta didik, tujuan instruksional khusus (TIK), alat penilaian hasil belajar, strategi instruksional, mengembangkan bahan instruksional, dan evaluasi 
formatif. Berdasarkan hasil kajian tersebut, diperoleh desain komponen model sebagai berikut.

\section{Analisis Kebutuhan Instruksional}

Proses pelaksanaan analisis kebutuhan didasarkan pada identifikasi atas kondisi yang diharapkan dan dibandingkan pada keadaan yang terjadi sekarang. Setiap keadaan yang kurang dari yang seharusnya berjalan seperti yang diinginkan dapat menunjukkan adanya suatu kebutuhan. Menurut Suparman (2012: 118) kebutuhan merupakan suatu kesenjangan yang terjadi saat ini dibandingkan dengan keadaan yang diinginkan.

Kebutuhan instuksional yang dibutuhkan diantaranya adalah karakteristik umum anak kelas $1 \mathrm{SD}$, sikap/perilaku anak kelas $1 \mathrm{SD}$ saat menerima pelajaran matematika, serta kompetensi yang harus dimiliki oleh peserta didik kelas 1 SD. Keteranganketerangan tersebut dapat diperoleh melalui hasil wawancara secara langsung kepada beberapa orang-oang terdekat yang langsung menangani peserta didik kelas $1 \mathrm{SD}$, yakni orangtua, wali kelas, guru, dan pengasuh anak. Hal ini dimaksudkan untuk mendapatkan informasi secara konkret mengenai karakteristik peserta didik serta kompetensi yang diharapkan dapat dicapai oleh peserta didik yang duduk di kelas $1 \mathrm{SD}$.

Dari hasil wawancara tersebut banyak diantara narasumber mengatakan bahwa peserta didik kelas 1 SD memiliki karakteristik yang tak jauh dari anak usia Taman Kanak-kanak. Umumnya perilaku mereka sangat aktif, memiliki rasa ingin tahu yang begitu besar, namun konsentrasi dan penalaran yang masih kurang baik dalam menerima materi pelajaran. Oleh karena itu sangat dibutuhkan sebuah pembelajaran dengan penyampaian menarik. Selain itu, hasil observasi ditemukan bahwa anak-anak kelas 1 masih sangat menyukai hal-hal yang konkret sedangkan matematika itu sendiri bersifat abstrak sehingga dalam penyampaian materi sangat diperlukan metode-metode yang menarik dan disukai mereka akan sangat senang dan mudah menerima. Sependapat hal tersebut, Alifah (wali kelas 1 SD Plus Bina Pendidikan) mengatakan "anak-anak kelas 1 SD lebih semangat belajar dengan alat bantu".

Selanjutnya, kompetensi yang ingin dicapai oleh peserta didik kelas 1 SD dari segi sikap dan perilaku, mereka lebih diinginkan untuk mandiri dan percaya diri dalam melakukan kegiatannya sehari-hari. Sedangkan dari segi akademik, mereka diinginkan untuk dapat menguasai pelajaran yang diajarkan didalam kelas, khususnya penguasaan dalam konsep penjumlahan dan pengurangan karena telah ditemukan bahwa siswa kelas 1 SD umumnya sudah pandai membilang.

\section{Tujuan Instruksional Umum}

Dari beberapa kompetensi yang diharapkan dapat dicapai oleh peserta didik kelas 1 SD dirancang Tujuan Instruksional Umum (TIU) untuk menentukan kompetensikompetensi yang akan dicapai oleh peserta didik di kelas 1 SD sesuai dengan keinginan dan harapan dari para orang tua atau wali peserta didik kelas 1 SD yang diharapkan mampu dicapai oleh peserta didik pada akhir proses pembelajaran. Menurut Suparman (2012: 149) menyebutkan bahwa "Isi tujuan instruksional adalah kompetensi dasar yang diharapkan dicapai peserta didik pada akhir pembelajaran". Tujuan instruksional umum inilah yang akan menjadi acuan untuk merangkai bahan pembelajaran yang sesuai dengan kompetensi-kompetensi yang diinginkan dapat dicapai oleh peserta didik.

Mulanya TIU disusun hanya satu untuk keseluruhan proses pembelajaran matematika SD kelas 1. Namun, setelah memperhatikan beberapa kompetensikompetensi yang diharapkan serta sub bab yang ada pada pelajaran Matematika SD kelas 1 saat ini sangat berbeda tema. Oleh karena itu, tidak memungkinkan jika dibuat hanya satu TIU. Maka dibuatlah tiga TIU dalam proses desain pembelajaran matematika SD 
kelas 1 ini. Hal ini dimaksudkan agar kompetensi Matematika diharapkan dapat tercapai dengan baik, sesuai dengan urutan-urutan dan berada pada komposisi yang pas untuk pencapaiannya secara bertahap.

\section{Analisis Instruksional}

Analisis instruksional terdiri uraian kompetensi, uraian peta kompetensi, dan peta kompetensi. Perumusan analisis instruksional merupakan penjabaran dari TIU yang berisi butiran-butiran tahapan kompetensi yang harus dicapai oleh peserta didik kelas 1 SD.

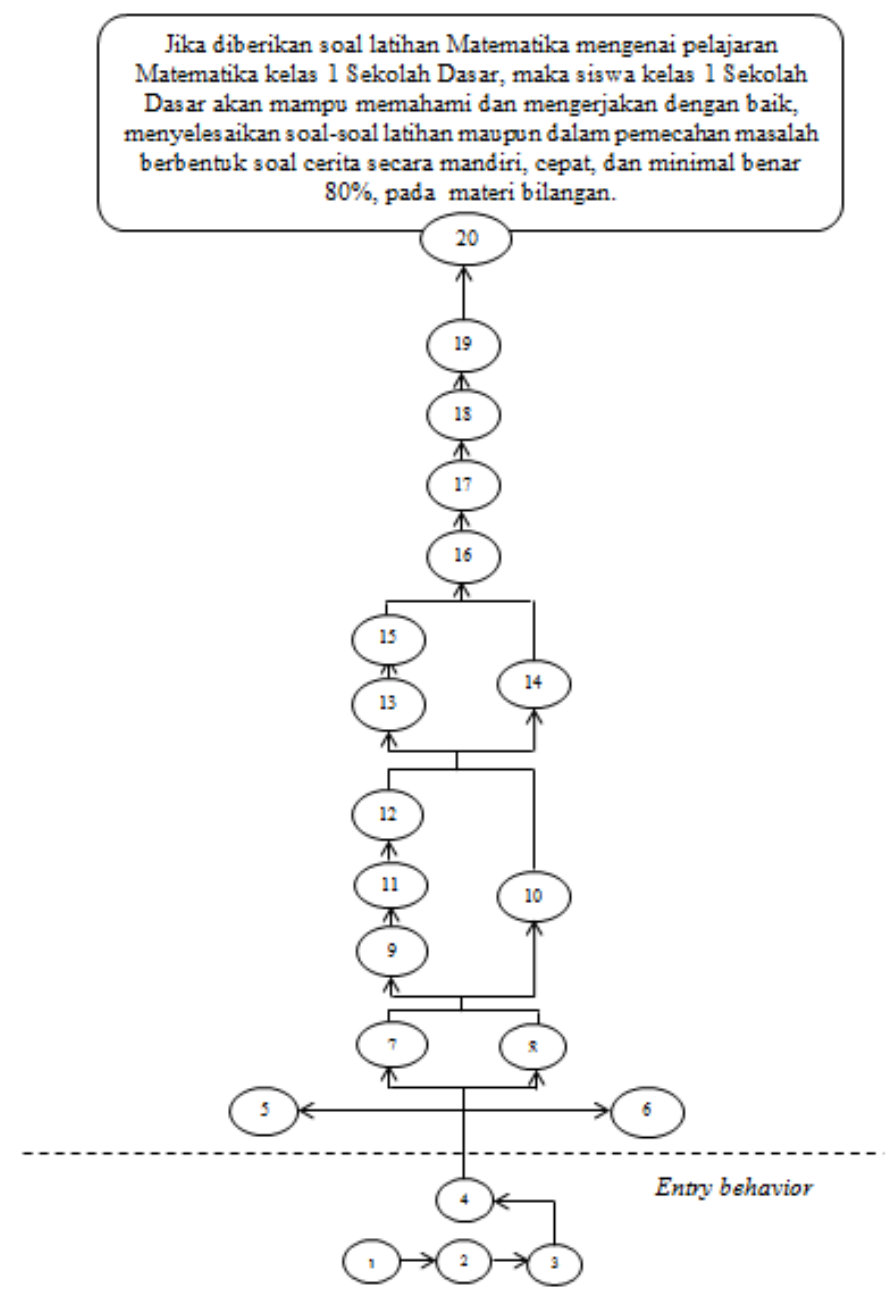

Gambar 1. Analisis Peta Kompetensi

Pada tahap ini pendesain merangkai langkah-langkah atau tahapan-tahapan pencapaian kompetensi peserta didik kelas $1 \mathrm{SD}$, mulai dari yang termudah hingga tersulit. Tahapan-tahapan ini nantinya akan dimasukan dalam bahan pembelajaran yang akan digunakan pada pembelajaran Matematika kelas 1 SD. Hasil dari analisis instruksional adalah peta subkompetensi atau peta kompetensi yang menunjukkan susunan subkompetensi yang paling dasar sampai kompetensi yang paling tinggi seperti dirumuskan dalam TIU.

Dalam proses pembuatan analisis instruksional, khususnya peta kompetensi sebaiknya memperhatikan struktur-struktur kompetensi, yang terdiri dari struktur hirarkis, struktur prosedural, struktur pengelompokkan, dan struktur kombinasi. Keempat struktur 
ini akan memudahkan dalam penyusunan peta kompetensi yang akan dicapai peserta didik. Peta kompetensi yang dimaksud dapat dilihat pada gambar 1.

Pada gambar 1 terlihat nomor-nomor yang mengerucut ke atas dengan kolom yang paling atas merupakan tujuan akhir pembelajaran, yakni Tujuan Instuksional Umum (TIU). Nomor tersebut merupakan urutan-urutan kompetensi yang harus dicapai oleh peserta didik. Urutan-urutan tersebut telah diuraikan sebelumnya pada uraian kompetensi dan di khususkan lagi pada uraian peta kompetensi. Terdapat pula garis putus-putus dengan bertuliskan "Entry Behavior", menunjukkan batasan kompetensi yang umumnya telah dikuasai oleh peserta didik, kompetensi tersebut berada dibawah garis entry behavior tersebut.

\section{Identifikasi Perilaku Peserta Didik Sekolah Dasar Kelas 1}

Menurut Suparman (2012: 180) bahwa peserta didik mempunyai implikasi terhadap penyusunan bahan dan sistem instruksional. Perilaku peserta didik inilah yang akan diamati dan hasilnya nanti merupakan dasar dalam mengembangkan sistem instruksional yang sesuai untuk peserta didik tersebut.

Masa usia Sekolah Dasar merupakan masa kanak-kanak akhir yang berlangsung dari usia enam tahun hingga usia dua belas tahun. Karakteristik utama siswa Sekolah Dasar adalah mereka yang menampilkan perbedaan-perbedaan dalam intelegensi, kemampuan dalam berpikir maupun berbahasa, perkembangan kepribadian, dan perkembangan fisik anak.

Proses identifikasi perilaku peserta didik SD kelas 1 ini hampir sama seperti identifikasi kebutuhan instruksional sebelumnya. Perbedaannya dalam identifikasi perilaku ini proses yang dijalankan hanyalah mencari dan mengamati pola perilaku saat ini mulai dari segi fisik, kecerdasan, dan sosial-emosional peserta didik kelas 1 SD.

Hasil observasi ditemukan bahwa umumnya peserta didik kelas 1 SD tergolong aktif, selalu bergerak dengan rasa keingintahuan yang cukup besar karena kemampuan berfikirnya yang masih terbatas sehingga apapun yang baru ia lihat dan dengar selalu saja ditanyakan. Namun dari segi emosionalnya belum terkontrol baik sehingga ia masih mudah terpengaruh dan dipengaruhi oleh lingkungan sekitar.

\section{Tujuan Instruksional Khusus}

Tujuan instruksional khusus (TIK) merupakan representatif dari tujuan instruksional umum (TIU) yang merupakan dasar dan pedoman bagi proses pengembangan instruksional. Sedangkan dalam proses-proses sebelumnya merupakan tahap pendahuluan untuk menghasilkan tujuan instruksional khusus.

Perumusan TIK ini akan sangat bergantung pada TIU. Setiap topik dalam TIU diuraikan menjadi subtopik dalam TIK. Oleh karena itu, TIU yang telah dibuat sebelumnya perlu dimatangkan secara isi. Jika terdapat perubahan pada TIU bisa jadi TIK dapat pula berubah.

Untuk proses penelitian ini telah terjadi dua kali perubahan dalam penyusunan TIK yang semula TIU hanya dibuat satu menyeluruh telah didapatkan delapan TIK. Kemudian pada hasil akhir TIU terbagi menjadi tiga bagian TIU dengan TIK yang masih sama yakni berjumlah delapan butir. Namun kedelapan TIK tersebut dipasangkan dengan masingmasing TIU agar TIU dengan TIK mendapatkan komposisi yang pas dan sesuai untuk hasil yang diharapkan.

\section{Rancangan Instrumen Penilaian}

Alat penilaian hasil belajar bertujuan untuk mengukur tingkat penguasaan peserta didik dalam setiap kompetensi pembelajaran. Menurut Suparman (2012: 210) bahwa alat 
penilaian dimaksudkan untuk mengukur kompetensi dalam kawasan taksonomi kognitif yang biasa disebut tes dalam bentuk tertulis atau lisan dan harus dujawab dengan tertulis atau lisan pula. Setiap alat penilaian hasil belajar yang relevan dengan TIK (Tujuan Instruksional Khusus) haruslah valid untuk digunakan.

Rancangan instrumen penilaian dalam proses desain ini berupa butir-butir soal yang akan diujikan pada proses akhir pembelajaran. Butir-butir soal yang dibuat penulis mengacu pada tabel spesifikasi tes yang komperensif. Tabel spesifikasi yang dibuat sekali lagi memperhatikan TIU dan TIK yang telah disusun sebelumnya. Tabel spesifikasi tes ini juga memuat indikator-indikator pencapaian siswa dalam pembelajaran Matematika kelas $1 \mathrm{SD}$.

Dalam pembuatan tabel spesifikasi tes pendesain mengamati indikator-indikator umum yang telah disusun oleh Depdiknas untuk mata pelajaran Matematika SD kelas 1 yang kemudian disesuaikan dengan kompetensi-kompetensi yang diharapkan dapat dicapai oleh peserta didik kelas 1 SD. Pada proses pengamatan tentu tidak langsung menemukan hasil mutlak, terdapat berbagai perubahan-perubahan dalam penyusunannya yang sangat bermanfaat untuk pembuatan butir-butir soal nantinya.

Tabel 1. Format Spesifikasi Tes Matematika Kelas I

\begin{tabular}{|c|c|c|c|c|c|}
\hline \multirow{2}{*}{$\begin{array}{c}\text { Tujuan } \\
\text { Instrulssional }\end{array}$} & \multirow{2}{*}{$\begin{array}{c}\text { Tes } \\
\text { Objeltif }\end{array}$} & \multirow{2}{*}{ Uraian Materi } & \multirow{2}{*}{ Indilcator Soal } & \multicolumn{2}{|c|}{ Bentulk Sosl } \\
\hline & & & & PG & Esai \\
\hline \multirow[t]{2}{*}{$\begin{array}{l}\text { Mengidentifikasi } \\
\text { bilangan }\end{array}$} & \multirow[t]{2}{*}{$\mathrm{Cl}_{1}$} & 1. Membilang & $\begin{array}{l}\text { 1. Membilang banyak benda } \\
\text { 2. Membilang } 1-100 \\
\text { 3. Menentukin bilangan }\end{array}$ & $\mathrm{x}$ & \\
\hline & & $\begin{array}{l}\text { 2. Mengurutkan } \\
\text { bilangan dan } \\
\text { banyak } \\
\text { benda }\end{array}$ & $\begin{array}{l}\text { 1. Membandingkan } \\
\text { mengurutkan banyak benda dan } \\
\text { yang paling sedikit } \\
\text { 2. Membandingkan } \\
\text { mengurutkan banyak benda dari } \\
\text { yang paling banyakk } \\
\text { 3. Membandingkan } \\
\text { mengurutkan bilangan sampai } \\
\text { 100 dari yang terkecil } \\
\text { 4. Membandingkan } \\
\text { mengurutkan bilangan sampai } \\
100 \text { dari yang terbesar }\end{array}$ & $\mathrm{x}$ & \\
\hline \multirow[t]{3}{*}{$\begin{array}{l}\text { Melakukcan } \\
\text { operasi hitung } \\
\text { penjumlahan dan } \\
\text { pengurangan } \\
\text { sederhana }\end{array}$} & \multirow[t]{3}{*}{$\mathrm{C}_{2}$} & 1. Penjumlahan & $\begin{array}{l}\text { 1. Mengenal konsep penjumlahan } \\
\text { 2. Menjumlahkan banyak benda } \\
\text { sampai } 20 \\
\text { 3. Menyelesaikan operasi hitung } \\
\text { penjumlahan bilangan sampai } 20 \\
\text { 4. Menentukan pasangan bilangan } \\
\text { dengan jumlah yang telah } \\
\text { diketahui } \\
\text { 5. Pola bilangan sederhana } \\
\text { (membilangloncat) }\end{array}$ & $\mathrm{x}$ & $\mathrm{x}$ \\
\hline & & 2. Pengurangan & $\begin{array}{l}\text { 1. Mengenal konsep pengurangan } \\
\text { 2. Menguranglan banyak benda } \\
\text { sampai } 10 \\
\text { 3. Menyelesaikan operasi hitung } \\
\text { pengurangan bilangan sampai } 10 \\
\text { 4. Menentulian pasangan bilangan } \\
\text { dengan selisih yang sudah } \\
\text { diketahui }\end{array}$ & $\mathrm{x}$ & $\mathrm{x}$ \\
\hline & & $\begin{array}{l}\text { 3. Penyelesaian } \\
\text { masalah }\end{array}$ & $\begin{array}{l}\text { 1. Menyelesaikan masalah yang } \\
\text { berkaitan dengan penjumlahan } \\
\text { dan atau pengurangan sampai } 20\end{array}$ & $\mathrm{x}$ & $\mathrm{x}$ \\
\hline $\begin{array}{l}\text { Mengidentifikasi } \\
\text { konsep nilai } \\
\text { tempat puluhan } \\
\text { dan satuan }\end{array}$ & $\mathrm{C}_{2}$ & $\begin{array}{l}\text { 1. Nilai tempat } \\
\text { puluhan }\end{array}$ & $\begin{array}{l}\text { 1. Mengenal nilai tempat puluhan } \\
\text { 2. Menunjukkcan nilai tempat } \\
\text { puluhan pada bentuk bilangan } \\
\text { 3. Menguraikan bentuk panjang nilai } \\
\text { tenpat puluhan dari suatu } \\
\text { bilangan }\end{array}$ & $\mathrm{x}$ & \\
\hline
\end{tabular}

Tabel spesifikasi pada tabel 1. sedikit terlihat seperti silabus dalam sebuah perangkat pembelajaran. Yang menjadi pembeda yakni adanya tujuan pembelajaran pada masing-masing tema yang terdapat pada tujuan instruksional. C1, C2, sampai C6 merupakan sebuah kriteria pencapaian yang tergambarkan dalam taksonomi Bloom. Materi-materi pelajaran yang telah terformat dalam tbel spesifikasi tersebut yang nantinya akan dijadikan sebuah acuan penilaian akhir tujuan pembelajaran berupa pembuatan soalsoal untuk mengukur kompetensi yang telah dicapai oleh peserta didik. 


\section{Strategi Instruksional}

Strategi instruksional menggambarkan komponen umum materi pembelajaran dan prosedur yang digunakan dalam mencapai hasil belajar (Yaumi, 2013: 207). Penyusunan strategi instruksional didasarkan pada tujuan instruksional yang akan dicapai sebagai kriteria umum.

Strategi pembelajaran perlu dipersiapkan agar pembelajaran dapat berjalan secara fokus dan terarah pada pencapaian kompetensi-kompetensi peserta didik. Isi pembelajaran untuk setiap TIK yang telah dirancang sebelumnya bersama komponen lain seperti langkah-langkah kegiatan instruksional, metode dan alat, serta media instruksional akan tergambar dalam strategi instruksional. Dengan kata lain, daftar isi pembelajaran akan dibuat pendesain instruksional pada saat menyusun strategi instruksional ini.

Dalam penyusunan strategi penulis perlu menguasai teknik dan metode-metode pembelajaran serta media pembelajaran yang akan digunakan. Metode dan media pembelajaran ini yang akan membantu proses penyampaian materi ajar kepada peserta didik. Namun yang terpenting adalah penulis mengetahui dan memahami materi pembelajaran yang diajarkan disekolah saat ini juga perlu diperhatikan.

Strategi pembelajaran akan sulit dibuat ketika penulis tidak mengetahui secara pasti materi dan proses pembelajaran yang umumnya telah berlangsung di lapangan. Strategi pembelajaran ini juga merupakan sebuah jawaban terhadap permasalahan-permasalah yang didapat saat analisis kebutuhan. Oleh karena itu, kesesuaian antara metode dan media pembelajaran dengan materi pembelajaran itu sendiri akan menghasilkan sebuah pembelajaran bermakna bagi peserta didik.

Pada proses ini, pendesain telah menyusun strategi pembelajaran pada setiap masing-masing TIK dengan dasar TIU. Strategi pembelajaran itu yang nantinya akan digunakan pada proses pembelajaran dikelas yang dikemas dengan adanya metode dan media pembelajaran hingga alokasi waktu yang telah terencana dengan baik. Semua ini diharapkan agar setiap tahapan dan pembahasan dalam TIK dapat terlaksana untuk tercapainya kompetensi-kompetensi dalam TIU.

\section{Mengembangkan Bahan Instruksional}

Bahan pembelajaran merupakan sebuah produk yang akan dihasilkan dari proses pengembangan desain pembelajaran Matematika SD kelas 1. Bahan pembelajaran ini memuat materi-materi pelajaran dan kegiatan lainya berupa latihan-latihan sebagai penunjang untuk tercapainya kopetensi-kompetensi peserta didik.

Dari segi muatan isi, bahan pembelajaran disusun dengan memperhatikan antara TIU dan TIK hingga strategi yang telah disusun sebelumnya. Beberapa buku-buku sekolah dijadikan referensi dalam pembuatan bahan pembelajaran ini. Dari segi desain atau tampilan bahan pembelajaran, dibuat semenarik mungkin dengan penggunaan warna-warna serta gambar-gambar menarik. Hal ini dimaksudkan agar peserta didik tidak merasa bosan dan jenuh saat proses pembelajaran berlangsung. Cover desain bahan instruksional yang telah dibuat dapat dilihat pada gambar 2. Pemilihan gambar-gambar yang menarik diimbangi dengan penggunaan warna-warna yang cerah telah terlihat cover baian awal hingga cover akhir

Pada awal bab dalam bahan instruksional tersebut dituliskan pula TIU, TIK, uraian materi, peta konsep hingga karakter yang akan dikembangkan dalam pelajaran tersebut. Berikut gambarannya. Penulisan TIU, TIK, hingga pada karekater yang dikembangkan untuk setiap bab dituliskan pada bagian awal bab bertujuan untuk mengingatkan bahwa dalam penjelasan materi pada masing-masing bab tersebut harus dapat tercapai 
kompetensi. Dengan begitu diharapkan tujuan akhir pembelajaran yang telah tertuang dalam TIU dapat tercapai. Hal ini dapat dilihat pada gambar 3.
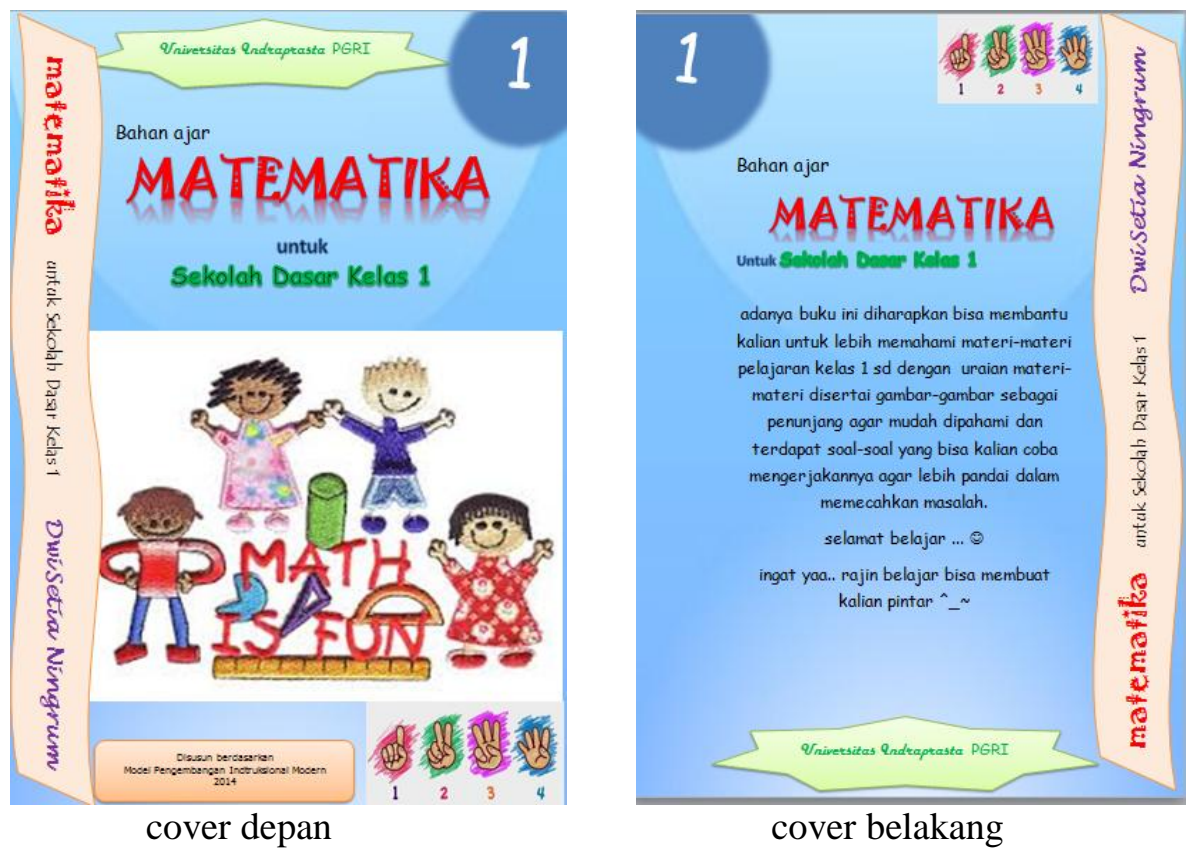

Gambar 2. Cover depan dan cover belakang bahan ajar
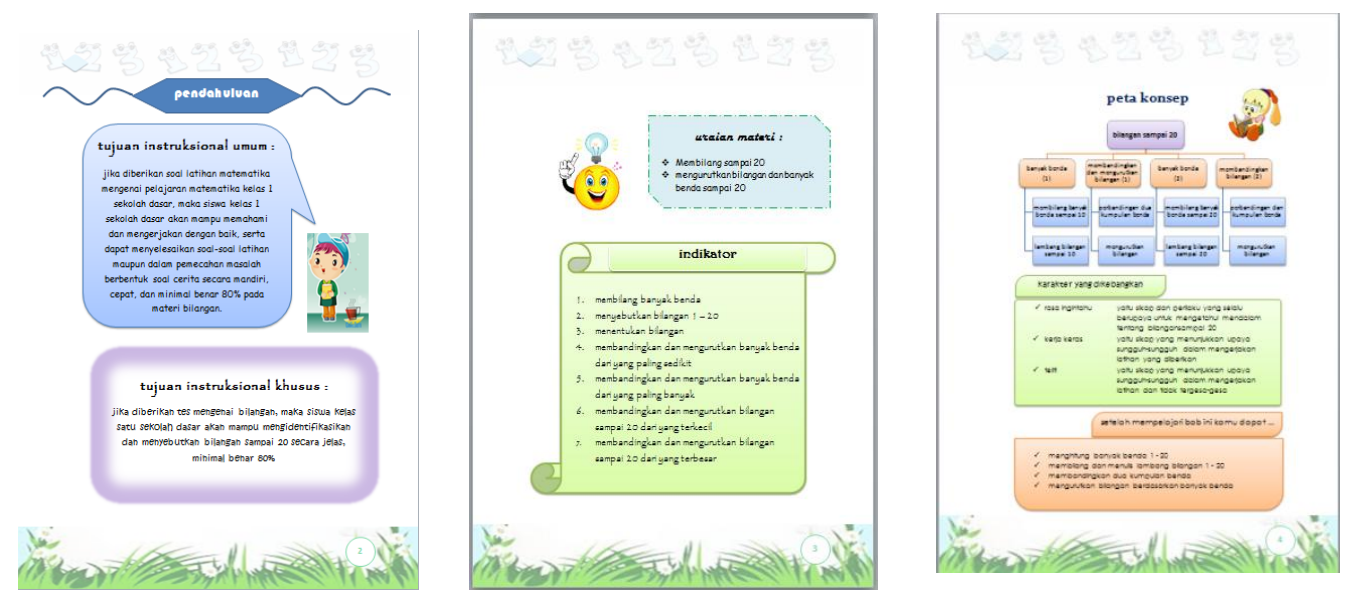

Gambar 3. Bagian awal bab bahan instruksional

Fokus pelajaran pada bahan pembelajaran Matematika Sekolah Dasar kelas 1 ini terdiri atas 6 bab, yaitu bilangan sampai 20, penjumlahan dan pengurangan sederhana, pengukuran panjang, tinggi, dan berat, bilangan sampai 99, penjumlahan dan pengurangan sampai 99, serta bangun datar sederhana. Semua materi dikemas dalam desain semenarik mungkin didukung dengan pemilihan gambar untuk memudahkan peserta didik memahami isi pelajaran sehingga kemampuan pemecahan masalah dapat terfasilitasi dengan baik. 

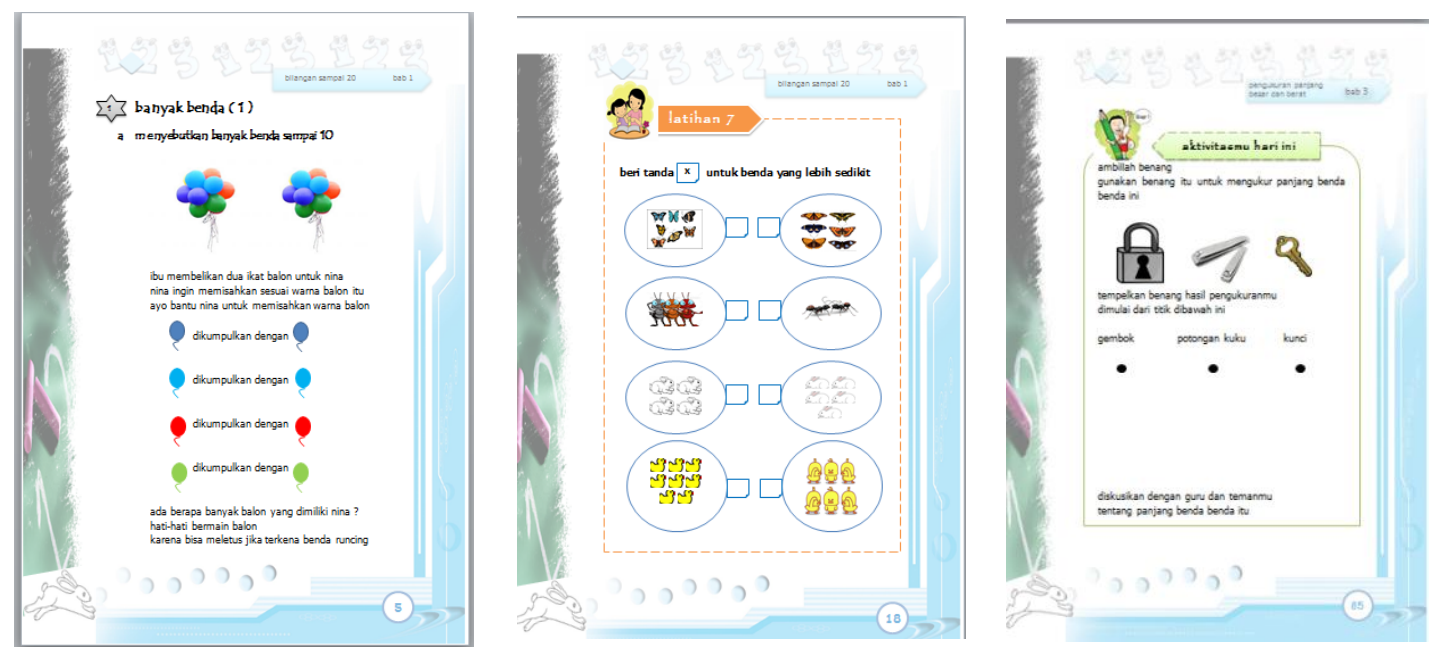

Gambar 4. Contoh isi bahan ajar instruksional Matematika kelas 1 SD

Selain latihan-latihan soal, didalam bahan ajar tersebut juga terdapat beberapa kegiatan-kegiatan atau tugas-tugas yang langsung dipraktekkan oleh pseserta didik agar mereka bisa langsung merasakan mencari pemecahan masalahnya sendiri. dengan hal ini diharapkan kemampuan pemecahan masalah matematika mereka dapat berkembang dengan baik.

\section{PENUTUP}

\section{Simpulan}

Bahan Ajar Matematika Sekolah Dasar kelas 1 dalam desain Instruksional yang dihasilkan ini telah dikembangkan dengan model pengembangan instruksional Atwi Suparman, meliputi tahap pendahuluan, analisis dan pengembangan prototype, serta melaksanakan evaluasi formatif. Pada tahap pendahuluan terdiri dari mengidentifikasi kebutuhan instruksional dan menulis tujuan instruksional umum, melakukan analisis instruksional, serta mengidentifikasi perilaku dan karakteristik awal peserta didik.

Pada tahap berikutnya, yakni analisis dan pengembangan prototype terdiri dari menulis tujuan instruksional umum, menulis alat penilaian hasil belajar, menyusun Strategi Instruksional, dan mengembangkan bahan instruksional. Untuk tahap terakhir dalam melaksanakan evaluasi formatif terdiri dari penelaahan oleh pakar dan revisi, evaluasi oleh 1-3 peserta didik dan revisi, uji coba dalam skala terbatas dan revisi, serta uji coba lapangan dengan melibatkan semua komponen dalam sistem sesungguhnya.

Penilaian kualitas bahan ajar dilaksanakan pada tahap evaluasi formatif oleh ketiga orang ahli yang terdiri dari ahli konten atau bidang studi, ahli pendesain instruksional lain, dan ahli produksi media, dalam hal ini adalah ahli desain grafis. Hasil dari penilaian ketiga orang ahli tersebut adalah bahan ajar instruksional yang telah tertata, terstruktur, dan terprogram dengan kualitas baik.

\section{Saran}

\section{Saran Pemanfaatan}

Bahan Ajar Matematika Sekolah Dasar kelas 1 dalam desain instruksional hasil penelitian ini sangat baik digunakan sebagai media atau sumber belajar dalam pembelajaran matematika dalam upaya memfasilitasi kemampuan pemecahan masalah matematis siswa. 
Untuk menghemat biaya pengadaan Bahan Ajar Matematika Sekolah Dasar kelas 1 dalam Desain Instruksional ini maka pengguna, baik guru maupun siswa dapat memanfaatkannya dalam bentuk softcopy.

\section{Saran Pengembangan Produk Lebih Lanjut}

Perlu dikembangkan Bahan Ajar Matematika Sekolah Dasar kelas 1 dalam desain Instruksional untuk memfasilitasi kemampuan pemecahan masalah pada pokok bahasan dan jenjang berikutnya. Selain itu, Bahan Ajar Matematika Sekolah Dasar kelas 1 dalam desain Instruksional ini dapat dijadikan sebagai acuan dalam mengembangkan bahan ajar tersebut dengan memperhatikan berbagai kekurangan dan kelebihan sehingga dihasilkan produk bahan ajar yang lebih baik.

Dalam proses pembelajaran perlu dikembangkan bahan ajar Matematika Sekolah Dasar kelas 1 dalam desain Instruksional yang mengintegrasikan dan diinterkoneksikan dengan sumber atau media pembelajaran lain yang lebih interaktif agar kegiatan pembelajaran dapat berjalan lebih efektif.

Bahan Ajar Matematika Sekolah Dasar kelas 1 dalam desain Instruksional ini dapat dikembangkan kembali dalam bentuk software macromedia atau adobe flash agar pembelajaran dengan menggunakan media tersebut lebih menarik dan menyenangkan.

\section{DAFTAR PUSTAKA}

Asrori, I. 2013. Pengembangan Desain Pembelajaran Teknologi Pendidikan Islam. Seminar Teknologi Pendidikan Islam. Tulung Agung: STAIN Tulung Agung.

Frengky. 2011. Model Pembelajaran Matematika Siswa Kelas Satu Sekolah Dasar. Psikologi, Vol.35 (2): 151-163.

Natalius. 2012. Pendidikan di Indonesia Memprihatinkan. http: //www.katanatalius.com/2012/11/pendidikan-di-indonesia-memprihatinkan.html. Di unduh pada 13 Februari 2014 Pkl. 05.40 WIB.

Sagala, S. 2011. Konsep dan Makna Pembelajaran. Bandung: Alfabeta.

Sinamo, J. 2010. 8 Etos Keguruan. Jakarta: Institut Darma Mahardika.

Soejadi, 2000. Kiat Pendidikan Matematika di Indonesia. Jakarta: Dirjen Dikti Depdikbud.

Suhendri, H. 2011. Pengaruh kecerdasan matematis-logis dan kemandirian belajar terhadap hasil belajar matematika. Formatif, 1 (1): 29-39.

Suherman, A. dkk.2010. The Development Of Instructional Design Model Of Productive Subjeck In The Implementation Of Competence-Based Curriculum In Technology And Engineering TVET. Bandung: Proceedings of the $1^{\text {st }}$ UPI International Conference on Technical and Vocational Education and Training.

Sujarwo. 2011. Desain Sistem Pembelajaran. Yogyakarta: PLS FIP UNY.

Suparman, M. A. 2012. Desain Instruksional Modern: Panduan Para Pengajar \& Inovator Pendidikan. Jakarta: Erlangga.

Yasin, S. 2012. Metode belajar dan pembelajaran yang efektif. Adabiyah, XII (1): 1-9.

Yaumi, M. 2013. Prinsip-Prinsip Desain Pembelajaran. Jakarta: Kencana. 